\title{
The Effect of the Training Program to Promote the Knowledge and Awareness of Prospective Preschool Teachers on Emotional Neglect and Abuse
}

\author{
Mehmet Kanak ${ }^{1} \Varangle$ \\ Neslihan Avci² (iD \\ ${ }^{\prime}$ Cumhuriyet University, Education Faculty, Turkey \\ Email:mehmetkanak58@gmail.com Tel:+9034.62191010/4637 \\ ${ }^{2}$ Gazi University, Gazi Education Faculty, Turkey
}

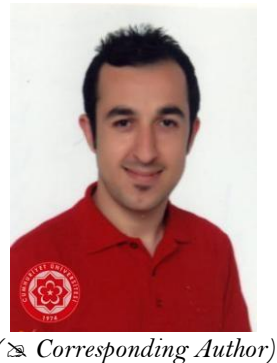

\begin{abstract}
The aim of the study was to investigate the effect of the " Training Program to Promote The Knowledge and Awareness of Prospective Preschool Teachers" developed to promote the knowledge and awareness of prospective preschool teachers concerning emotional neglect and abuse. The study group comprised a total of 120 prospective teachers $(60$ prospective teachers in the experimental group and 60 prospective teachers in the control group) attending Cumhuriyet University, Faculty of Education, Department of Preschool Education in 2014-2015 school year. The pre-test post-test-follow up-test experimental model was used in the study. The "Emotional Neglect/Abuse Knowledge and Awareness Scale" was used to assess the knowledge and awareness of prospective teachers on emotional neglect and abuse, "The Training Program to Promote The Knowledge and Awareness of Prospective Preschool Teachers" was administered to the experimental group whereas the control group received no administration. In data analysis, ttest for related samples was used in pre-test and post-test, and post-test and follow up test comparisons, while a single factor ANOVA with repeated measures was performed for pre-test, post-test and follow up test multiple comparison. Research results revealed a significant difference in favor of the experimental group between the post-test scores of the participants in the experimental and control groups with regard to rejection and ignoring, insulting and exposing the child to violence, isolation and threatening, comparison and discrimination subscales of the "Emotional Neglect/Abuse Knowledge and Awareness Scale" ( $p<.05)$. Furthermore, the results of the follow up test administered four weeks after the post-test showed that the effect of the training was still retained $(p>.05)$. In accordance with these results, it was concluded that the research affected prospective teachers' knowledge and awareness levels of emotional neglect and abuse.
\end{abstract}

Keywords: Emotional neglect, Emotional abuse, Awareness, Prevention, Child.

Citation | Mehmet Kanak; Neslihan Avcı (2018). The Effect of the Training Program to Promote the Knowledge and Awareness of Prospective Preschool Teachers on Emotional Neglect and Abuse. Asian Journal of Education and Training, 4(2): 137-145. History:

Received: 24 August 2016

Revised: 1 September 2016

Accepted: 26 September 2016

Published: 4 April 2018

Licensed: This work is licensed under a Creative Commons Attribution 3.0 License (c))

Publisher:Asian Online Journal Publishing Group
Contribution/Acknowledgement: Both authors contributed to the conception and design of the study.

Funding: This study received no specific financial support

Competing Interests: The authors declare that they have no conflict of interests.

Transparency: The authors confirm that the manuscript is an honest, accurate, and transparent account of the study was reported; that no vital features of the study have been omitted; and that any discrepancies from the study as planned have been explained.

Ethical: This study follows all ethical practices during writing.

\section{Contents}

1. Introduction

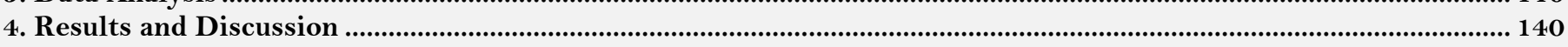

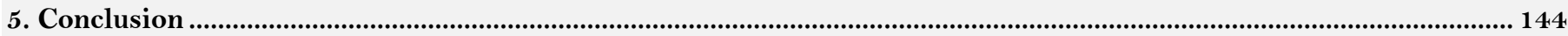

References 


\section{Introduction}

Emotional abuse in educational settings is a repetitive harmful interaction between teacher and student. Teachers' emotionally abusive behaviors include shouting to make students cry, offending or hurting them, and calling them idiot or stupid (Okoza et al., 2011). Emotional neglect and abuse can lead to several pathologies in children depending on their age and period of development (Yavuzer, 1992). The effect of emotional violence on students' learning is indisputable (Okoza et al., 2011). Thus, teachers should be informed about child abuse through in-service training during and after their university education and trained to recognize abused children (Şahin and Beyazova, 2001).

Walsh et al. (2005) investigated Australian teachers' education in child neglect, abuse, and protection and reported that $7 \%$ of 254 teachers did not receive training in the subject. In a study conducted in Turkey, Tugay (2008) found that $93.8 \%$ of 400 teachers received no training in the subject. Can-Yaşar et al. (2014) reported that $85.73 \%$ of preservice teachers were not informed of the Child Protection Law and 39.01\% were not confident of defining the manifestations of physical abuse. They also reported that among the preservice teachers involved in the study group, those studying Preschool Teacher Education took the class "Child Neglect and Abuse" as an elective course; however, those studying other fields (Classroom, Social Studies, and Turkish Language Teaching) did not receive any training in the subject. Pala (2011) noted that $91.2 \%$ of preservice teachers lacked education about child neglect and abuse.

Erol (2007) analyzed the level of awareness of physical abuse in teachers working in preschool institutions and argued that teachers were insufficient to detect child abuse symptoms. Accordingly, she recommended informing and training preschool teachers through central and local in-service training activities organized by the Ministry of National Education and Provincial Directorates of National Education. In a similar vein, Sahin and Taşar (2012) noted the necessity to initiate preventive actions through formal educational programs. They also argued that a new program suitable for Turkey had to be designed using foreign examples proven to be effective.

It is the primary prevention activities that should first be undertaken to prevent child abuse. Primary prevention activities are organized for students, parents, and school staff children interact with in school settings (Bolen, 2003). Teachers can recognize any difference better because they see children together with their peers. For example, an experienced teacher informed of child abuse takes care of any scar or bruise on a student's face or body and investigates what happened to him or her. Such a teacher can also observe changes in a student's behavior including withdrawal, unhappiness, malaise, lack of attention, aggression, bad temper, and poor school performance. A teacher observing any problem can create a suitable environment to allow a student to open up. Thus, this teacher can contribute to finding useful solutions for such students (Şahin and Beyazova, 2001). Teachers occupy crucial roles in educating parents of their students and other individuals to raise the society's awareness of child abuse (Şahin and Beyazova, 2001).

Tugay (2008) noted that $98.3 \%$ of teachers lacked training in the subject and thus, had to be informed of child neglect and abuse through in-service training. Such training for teachers will help raise not only teachers' awareness but also students' and parents' awareness. A teacher finding a chance for self-evaluation will take care not to hold an abusive position, unwittingly though. Thus, "child-friendly teachers" informed of the protection and non-violation of children's rights will act responsibly to safeguard their rights. Preservice teachers can be helped to become child-friendly teachers through preservice awareness-raising educational activities. Pala (2011) emphasizes that children spend most of their time with teachers after their family; therefore, teachers should be assisted in the issue of child neglect and abuse through preservice and in-service training as from their early education.

Can-Yaşar et al. (2014) recommend fostering teachers' awareness of child neglect and abuse through preservice training activities. Pre-school teachers play major roles in preventing child neglect and abuse and promoting children's social and emotional development through daylong activities and training programs. There are information- and awareness-raising activities aiming to prevent child abuse and neglect; however, there is a lack of supportive educational programs specifically designed for emotional abuse.

\subsection{Research Purpose}

This study aims to analyze the effectiveness of the "Training Program to Promote Preservice Preschool Teachers' Knowledge and Awareness of Emotional Neglect and Abuse" developed to foster preservice preschool teachers' knowledge and awareness of emotional neglect and abuse and to help them become child-friendly teachers. In line with this main purpose, this study seeks an answer to the following sub-research problems.

\subsection{Sub-Problems}

1. Does the Training Program to Promote Preservice Preschool Teachers' Knowledge and Awareness of Emotional Neglect and Abuse have an effect on preservice teachers' knowledge and awareness of emotional neglect and abuse?

2. Does the Training Program to Promote Preservice Preschool Teachers' Knowledge and Awareness of Emotional Neglect and Abuse have a permanent effect on preservice teachers' knowledge and awareness of emotional neglect and abuse?

\section{Methodology}

This study analyzes the effect of the Training Program to Promote Preservice Preschool Teachers' Knowledge and Awareness of Emotional Neglect and Abuse. To this end, it employs a pre-test post-test control group design that requires measurement in control group and experimental groups before and after the training. The dependent variable of the study is "preservice preschool teachers' level of knowledge and awareness of emotional neglect/abuse" and the independent variable is "the Training Program to Promote Preservice Preschool Teachers' Knowledge and Awareness of Emotional Neglect and Abuse".

As noted by Karasar (2006); Pala (2011) the research design can be represented as follows: 


\begin{tabular}{l|l|l|l|l|l}
\hline Pre-test & \multicolumn{2}{c}{ Post-test } & \multicolumn{2}{c}{ Retention Test } \\
\hline EG & R & O1 & X1 & O3 & O5 \\
\hline CG & R & O2 & & O4 & \\
\hline
\end{tabular}

EG: Experimental group undergoing the Training Program to Promote Pre service Preschool Teachers' Knowledge and Awareness of Emotional Neglect/Abuse.

CG: Control group

R: Random sampling of subjects

O1 and O3: Pre-test and post-test scores of the experimental group (receiving the training) O2 and O4: Pre-test and post-test scores of the control group (not receiving the training)

O5: Retention test scores of the experimental group (receiving the training)

X1: The independent variable applied to the experimental group (the Training Program to Promote Preservice Preschool Teachers' Knowledge and Awareness of Emotional Neglect and Abuse)

The presence of pre-tests in a pre-test post-test control group design helps determine the level of pre-test similarity between groups and accordingly correct post-test results. In this model, pre-test and post-test results are combined to determine the extent to which "X" is effective (Karasar, 2006).

\subsection{The Study Group for the Training Program to Promote Pre service Preschool Teachers' Knowledge and Awareness of Emotional Neglect and Abuse}

This study uses the concepts training group and non-training group to refer to the study group instead of experimental and control groups due to ethical rules that should be considered in studies with people.

Among 153 pre service teachers in the study group, 120 pre service teachers willing to participate in the study were involved in the second phase of the study. 120 participants were equally divided into two groups (each involving 60 participants) to reflect a similar distribution of scores.

Table-1. Demographical Data of the Participants in the Study Group for the Training Program to Promote Pre service Preschool Teachers' Knowledge and Awareness of Emotional Neglect and Abuse

\begin{tabular}{l|l|l|l|l|l|l}
\hline Variables & Subcategories & Training group * & \multicolumn{2}{l|}{ Non-training group* } \\
\hline & & $\mathbf{f}$ & \% & f & \% \\
\hline Sex & Female & 51 & 85 & 49 & 81,6 \\
\hline & Male & 9 & 15 & 11 & 18,4 \\
\hline Age & 21 and under & 44 & 78,3 & 50 & 83,3 \\
\hline & 22 & 16 & 26,7 & 8 & 13,4 \\
\hline & 23 & - & - & 2 & 3,3 \\
\hline
\end{tabular}

As seen in Table, $85 \%$ participants in the training group are female and $15 \%$ are male. $81.6 \%$ participants in the non-training group are female and $18.3 \%$ are male.

Considering the age distribution of participants in the training group, $1.7 \%$ are 20 years old, $76.7 \%$ are 21 , and $26.7 \%$ are 22. Considering the age distribution of participants in the non-training group, $3.3 \%$ are 20 years old, $80 \%$ are $21,13.3 \%$ are 22 , and $3.4 \%$ are 23 .

\subsection{Data Collection Tools}

The data was using the "Knowledge and Awareness of Emotional Neglect/Abuse Scale (KAENS)". As a result of the exploratory factor analysis (EFA), the KAENS reached a structure consisting of 4 sub-scales and 38 items. This measurement tool was designed as vignettes (short scenarios). As a result of the varimax rotation, the Cronbach's alpha coefficients were calculated 0.82 for the total scale and 4 sub-scales

\begin{tabular}{|c|}
\hline - Preliminary \\
\hline - Literature Search \\
\hline - Creating Content Titles \\
\hline - Creating Objectives and Acquisitions \\
\hline - Designing Activities \\
\hline - Expert Opinion \\
\hline - Review and Edit \\
\hline
\end{tabular}

The training program employed in this study is designed to foster preservice preschool teachers' knowledge and awareness of emotional neglect and abuse they often encounter in daily life and in educational settings. Before the development of the program, a need analysis was conducted and preliminary data was collected to design activities based on preservice teachers' views. The research participants hold the view that current debate techniques they previously did not have the opportunity to implement would keep program involvement alive. The program primarily involves the most demanded active learning methods and techniques such as four corners, mock court, Socratic method, letter invitation, and speech circle. The training program aiming to promote preservice teachers' knowledge and awareness of emotional neglect and abuse involves 37 objectives and 169 acquisitions in total. After the program was presented to three child development and education specialists and one program 
development specialist to deliver their opinions, it was given the final shape. The program was applied to three different groups through focus-group interviews for nine weeks. Each week's session involves three activities and the average time allocated for each activity is 50 minutes. The program was applied to the participants in the training group (focus groups) for a period of two months.

\section{Data Analysis}

SPSS 20 software was used to analyze the data collected through the "Knowledge and Awareness of Emotional Neglect/Abuse Scale (KAENS)". To determine the statistical method to be used for testing the effectiveness of the "Training Program to Promote Preservice Preschool Teachers' Knowledge and Awareness of Emotional Neglect and Abuse", the normality distributions were first examined. For this purpose, histograms with skewness-kurtosis values and normal distribution curve were drawn (Büyüköztürk, 2009). Considering the pre-test and post-test scores of the non-training group and the pre-test, post-test and retention test scores of the training group on the "Knowledge and Awareness of Emotional Neglect/Abuse Scale (KAENS)", the skewness value ranges from -1.105 to -932 and the kurtosis value ranges from .862 to .360 for the non-training group; the skewness value ranges from -1.114 to -1.358 and the kurtosis value ranges from .378 to 1489 for the training group; and the skewness value is -873 and the kurtosis value is .107 for the retention test. The fact that these values are within the accepted range of $-2-+2$ shows the normal distribution of the data (Büyüköztürk, 2009).

Parametric statistical methods were used assuming that the distribution is normal based on the skewnesskurtosis values. The independent samples t-test was performed to determine whether there is a difference in pretest scores of the training and non-training groups on the "Knowledge and Awareness of Emotional Neglect/Abuse Scale (KAENS)". In order to determine the difference in the pre-test and post-test scores of both the training and non-training groups, the "difference score" was calculated by subtracting the pre-test scores from the post-test scores to check the effect of the pre-test scores on the final test. The difference scores were compared using t-test.

The paired sample t-test was performed to analyze the pre-test, post-test and retention test scores of the participants in the training group. One-way ANOVA for repeated measures was used to statistically support the results in multiple comparisons. This technique tests whether there is a statically significant difference in the mean scores of two or multiple related measurement sets (Büyüköztürk, 2002). Prior to the analysis, the assumption of homogeneity of variances was tested. As the assumption was not met, the degree of freedom was adjusted by the epsilon value and ANOVA $F$ values were used. The e psilon values were less than $0.75[\mathcal{E}<0.75]$. Based on this conclusion, the results of the Bonferroni multiple compariPost-test and Greenhouse-Geisser correction are included in the ANOVA table (Can, 2014).

\section{Results and Discussion}

The following results were found in the study investigating the effect of the Training Program to Promote Preservice Preschool Teachers' Knowledge and Awareness of Emotional Neglect and Abuse:

- Tables show the t-test and ANOVAresults of the mean pre-test, post-test and retention test scores obtained by the training and non-training groups on the "Knowledge and Awareness of Emotional Neglect/Abuse Scale (KAENS)".

\subsection{The Results of the Pre-test Scores of the Participants in Training and Non-training Groups on the KAENS}

This study seeks answer to the question "Is there a significant difference in the pre-test scores of the training and non-training groups on the "Knowledge and Awareness of Emotional Neglect/Abuse Scale (KAENS)" before the implementation of the Training Program to Promote Preservice Preschool Teachers' Knowledge and Awareness of Emotional Neglect and Abuse.

The independent samples t-test was performed to compare the mean pre-test scores of training and nontraining groups.

Table-2. Participant's KAENS Pre-Test Scores

\begin{tabular}{l|l|l|l|l|l|l|l}
\hline Sub-Scale & Group & $\mathbf{N}$ & $\overline{\mathbf{X}}$ & $\mathbf{S S}$ & $\mathbf{s d}$ & $\mathbf{t}$ & $\mathbf{p}$ \\
\hline Rejection and Ignorance & Training & 60 & 6,42 &, 512 & 118 & 1,351 &, 179 \\
& Non-training & 60 & 6,25 &, 856 & & \\
\hline Humiliation and Witnessing the Child & Training & 60 & 6,33 &, 508 & 118 & 1,916 &, 058 \\
& Non-training & 60 & 6,08 &, 856 & & & \\
\hline Isolation and Threatening & Training & 60 & 5,85 &, 508 & 118 &,- 263 &, 793 \\
& Non-training & 60 & 5,89 &, 841 & & \\
\hline Comparison and Discrimination & Training & 60 & 6,03 &, 574 & 118 & 1,254 &, 212 \\
& Non-training & 60 & 5,87 &, 829 & & \\
\hline KAENS Total & Training & 60 & 6,15 &, 344 & 118 & 1,447 &, 151 \\
& Non-training & 60 & 6,01 &, 638 & & &
\end{tabular}

$\overline{\mathrm{p}>, 05}$

As seen Table 2, there is no statistically significant difference in the mean pre-test scores obtained by the training and non-training groups on the KAENS' sub-scale RI $[\mathrm{t}(118)=1.351$, p>.05], the sub-scale HWC $[\mathrm{t}(118)=1.916, \mathrm{p}>.05]$, the sub-scale IT $[\mathrm{t}(118)=-.263, \mathrm{p}>.05]$, the sub-scale $\mathrm{CD}[\mathrm{t}(118)=1.254$, $\mathrm{p}>.05]$, and the total KAENS $[\mathrm{t}(118)=1.447, \mathrm{p}>.05]$.

Considering the pre-test scores of the training and non-training groups on the total KAENS and the subscales, the mean scores of the participants in both groups are close. This result indicates that the participants in the training and non-training groups have similar traits before the implementation of the training program. In a pretest post-test control group research designs, pre-test scores of experimental and control groups should be close 
(Kaptan, 1998). The closeness of the pre-test scores of the experimental (training) and control (non-training) groups is important for the effectiveness of the training program.

The pre-test study identifies preservice teachers' knowledge and awareness of emotional neglect and abuse. As this study has no intention to give a comment on preservice teachers' current level of knowledge and awareness, it involves no indication that their level is low or high.

\subsection{The Results of the Effect of the Training Program to Promote Preservice Preschool} Teachers' Knowledge and Awareness of Emotional Neglect and Abuse

This study seeks an answer to the question "Is there a significant difference in the pre-test and post-test scores of the training group on the KAENS after the implementation of the Training Program to Promote Preservice Preschool Teachers' Knowledge and Awareness of Emotional Neglect and Abuse. The comments on the effectiveness of the training program will be presented as a whole after the tables and figures.

The paired sample t-test was used to analyze whether there is a significant difference in the pre-test and posttest scores of the training group.

Table-3. Comparison of the Mean Pre-test and Post-test Scores of the Training Group on the KAENS

\begin{tabular}{l|l|l|l|l|l|l|l}
\hline Sub-Scale & Group & $\mathbf{N}$ & $\overline{\mathbf{X}}$ & $\mathbf{S S}$ & $\mathbf{s d}$ & $\mathbf{t}$ & $\mathbf{p}$ \\
\hline Rejection and Ignorance & Pre-test & 60 & 6,42 &, 512 & 59 & $-7,165$ &, 000 \\
& Post-test & 60 & 6,88 &, 174 & & & \\
\hline Humiliation and Witnessing the & Pre-test & 60 & 6,33 &, 508 & 59 & $-7,123$ &, 000 \\
Child & Post-test & 60 & 6,84 &, 188 & & & \\
\hline Isolation and Threatening & Pre-test & 60 & 5,85 &, 508 & 59 & $-14,710$ &, , 000 \\
& Post-test & 60 & 6,81 &, 178 & & & \multirow{2}{*}{, 000} \\
\hline Comparison and Discrimination & Pre-test & 60 & 6,03 &, 574 & 59 & $-8,423$ & \\
& Post-test & 60 & 6,74 &, 292 & & &, 000 \\
\hline KAENS Total & Pre-test & 60 & 6,15 &, 344 & 59 & $-13,727$ &, 173 \\
\hline p<,001 & Post-test & 60 & 6,82 & & & & \\
\hline
\end{tabular}

As seen in Table 3, there is a statistically significant difference in the mean scores obtained by the training group on the KAENS' sub-scale RI [t(59)= -7.165 p<.001], the sub-scale HWC [t(59)=-7.123, p<.001], the subscale IT alt $[\mathrm{t}(59)=-14.710, \mathrm{p}<.001]$, the sub-scale $\mathrm{CD}[\mathrm{t}(59)=-8.429, \mathrm{p}<.001]$, and the total KAENS $[\mathrm{t}(59)=-$ $13.727, \mathrm{p}<.001]$. The difference in the mean pre-test and post-test scores of the training group on the total KAENS and sub-scales was found significant for the post-test.

Table-4. Comparison of the Mean Pre-test and Post-test Scores of the Non-Training Group on the KAENS

\begin{tabular}{|c|c|c|c|c|c|c|c|}
\hline Sub-Scale & Group & $\mathbf{N}$ & $\overline{\mathbf{X}}$ & SS & sd & $\mathbf{t}$ & $\mathbf{p}$ \\
\hline Rejection and Ignorance & $\begin{array}{l}\text { Pre-test } \\
\text { Post-test }\end{array}$ & $\begin{array}{l}60 \\
60\end{array}$ & $\begin{array}{l}6,25 \\
6,41\end{array}$ & $\begin{array}{l}, 856 \\
, 474\end{array}$ & 59 & $-1,703$ & ,094 \\
\hline $\begin{array}{l}\text { Humiliation and Witnessing the } \\
\text { Child }\end{array}$ & $\begin{array}{l}\text { Pre-test } \\
\text { Post-test }\end{array}$ & $\begin{array}{l}60 \\
60 \\
\end{array}$ & $\begin{array}{l}6,08 \\
6,05\end{array}$ & $\begin{array}{l}, 890 \\
, 787 \\
\end{array}$ & 59 & ,258 & ,798 \\
\hline Isolation and Threatening & $\begin{array}{l}\text { Pre-test } \\
\text { Post-test }\end{array}$ & $\begin{array}{l}60 \\
60 \\
\end{array}$ & $\begin{array}{l}5,89 \\
5,91 \\
\end{array}$ & $\begin{array}{l}, 841 \\
, 897 \\
\end{array}$ & 59 &,- 146 & ,884 \\
\hline Comparison and Discrimination & $\begin{array}{l}\text { Pre-test } \\
\text { Post-test }\end{array}$ & $\begin{array}{l}60 \\
60\end{array}$ & $\begin{array}{l}5,87 \\
5,86\end{array}$ & $\begin{array}{l}, 829 \\
, 863 \\
\end{array}$ & 59 &, 133 & ,895 \\
\hline KAENS Total & $\begin{array}{l}\text { Pre-test } \\
\text { Post-test }\end{array}$ & $\begin{array}{l}60 \\
60\end{array}$ & $\begin{array}{l}6,01 \\
6,05\end{array}$ & $\begin{array}{l}, 638 \\
, 528\end{array}$ & 59 &,- 398 & ,692 \\
\hline
\end{tabular}

As seen in Table 4, there is no statistically significant difference in the mean scores obtained by the nontraining group on the KAENS' sub-scale RI [ $\mathrm{t}(59)=-1.703, \mathrm{p}>.05]$, the sub-scale $\mathrm{HWC}[\mathrm{t}(59)=.258, \mathrm{p}>.05]$, the sub-scale IT $[\mathrm{t}(59)=-.146, \mathrm{p}>.05]$, the sub-scale $\mathrm{CD}[\mathrm{t}(59)=.133, \mathrm{p}>.05]$, and the total KAENS $[\mathrm{t}(59)=-.398$, $\mathrm{p}>.05]$.

Table-5. Comparison of the Participants' Post-test Scores on the KAENS

\begin{tabular}{l|l|l|l|l|l|l|l}
\hline Sub-Scale & Group & $\mathbf{N}$ & Mean dif. & $\mathbf{S S}$ & $\mathbf{s d}$ & $\mathbf{t}$ & $\mathbf{p}$ \\
\hline Rejection and Ignorance & Training & 60 & 0,46 &, 498 & 101,346 & 2,479 &, $015^{* *}$ \\
\hline & $\begin{array}{l}\text { Non- } \\
\text { training }\end{array}$ & 60 & 0,16 &, 766 & & & \\
\hline \multirow{2}{*}{ Humiliation and Witnessing the Child } & Training & 60 & 0,51 &, 504 & 118 & 3,680 &, $000^{*}$ \\
\hline & $\begin{array}{l}\text { Non- } \\
\text { training }\end{array}$ & 60 & $-0,33$ & 1,002 & & & \\
\hline Isolation and Threatening & Training & 60 &, 958 &, 504 & 84,479 & 6,195 &, $000^{*}$ \\
\hline & $\begin{array}{l}\text { Non- } \\
\text { training }\end{array}$ & 60 &, 020 & 1,059 & & & \\
\hline Comparison and Discrimination & Training & 60 &, 710 &, 652 & 118 & 5,525 &, $000^{*}$ \\
\hline & $\begin{array}{l}\text { Non- } \\
\text { training }\end{array}$ & 60 & $-0,13$ &, 776 & & & \\
\hline KAENS Total & Training & 60 &, 669 &, 377 & 94,110 & 6,492 &, $000^{*}$ \\
\hline
\end{tabular}


As seen in Table 5, there are statistically significant differences in the mean post-test scores obtained by the training and non-training groups on the KAENS' sub-scale RI $[\mathrm{t}(101.346)=2.479$, p<.05], the sub-scale HWC $[\mathrm{t}(118)=3.680, \mathrm{p}<.001]$, the sub-scale IT $[\mathrm{t}(84.479)=-6.195, \mathrm{p}<.001]$, the sub-scale CD $[\mathrm{t}(118)=5.525, \mathrm{p}<.001]$, and the total KAENS $[\mathrm{t}(94.110)=6.492, \mathrm{p}<.001]$. These differences are in favor of the training group.

As seen in the Table, it is expected that the mean scores of the training group on the total KAENS and subscales are higher than those of the non-training group and this difference is significant in the total scale and subscales. According to the research findings, the participants in the training group obtained higher scores than those in the non-training group.

Thus, it seems that the "Training Program to Promote Preservice Preschool Teachers' Knowledge and Awareness of Emotional Neglect and Abuse" fosters the participants' knowledge and awareness of emotional neglect and abuse. The literature search indicates several studies reporting similar results. Hebert et al. (2001) administered a child sexual abuse prevention program to 133 children of first to third grades and found that children involved in the prevention program showed greater preventive knowledge and skills compared to children not participating. According to Ko and Merith (2001) high school students attending the school-based abuse prevention program showed a visible increase in the level of knowledge about abuse concepts. Peterson $\mathrm{et}$ al. (2003) reported that participants, after the child maltreatment prevention program reduced their use of spanking and violence towards children and lessened their unrealistic and dangerous beliefs about children by increasing their use of temperate discipline and skills. These results show that such preventive interventions have both cognitive (beliefs) and behavioral (spanking and violence) effects. Campbell and Wigglesworth (2005) argue that teachers can properly perform their role in detecting abuse only when they are equipped with the relevant skills. They highlight the importance of in-service training in child protection for teachers noting that teachers' knowledge of the indicators of child abuse was reasonably good after the training.

Walsh et al. (2005) reported that 93\% of teachers received training in child abuse and after this training they assumed responsibility to report suspicions of child abuse although they did not feel confident of defining neglect and abuse. In a critical study on the impact of prevention programs, MacMillan et al. (2005) hold the view that prevention programs have positive outcomes but are not very effective in domestic physical abuse, neglect and crime. Their view disagrees with the results of this study. Sarı (2010) reported a significant decrease in the potential abuse scores of the experimental group after the training. This result was associated with the effectiveness of the implemented training program.

The likelihood of child abuse and violence has declined significantly and these training activities are tremendously useful to children. Çeçen-Eroğul and Kaf-Hasırcı (2013) administered a sexual abuse prevention psychoeducation program to elementary school fourth-grade students and proved the effectiveness of the program through the higher scores of children attending program compared to those not attending. Uçar (2014) noted that the training program designed based on a cognitive process approach was effective in helping participants acquire the skill to prevent sexual abuse.

These research results comply with the present study that finds a positive change in the total KAENS and subscale scores after the training and indicates the effectiveness of the training program.

Preservice teachers' high level of participation in activities using the mock court and Socratic seminar techniques and their oral feedbacks have a considerable role in the effectiveness of the program. Among the main features of the training program, the balanced distribution of the activities seems to positively contribute to the active participation of preservice teachers in the program and to the effectiveness of the program. It is also an expected result that there is no visible difference between the pre-test and post-test scores of participants in the non-training group. This result was influenced by the fact that participants in the non-training group receive no training in or information on child abuse within the scope of their undergraduate education simultaneously with this experimental research.

\subsection{The Results of the Permanence of the Effectiveness of the Training Program to Promote Preservice Preschool Teachers' Knowledge and Awareness of Emotional Neglect and Abuse}

\begin{tabular}{|c|c|c|c|c|c|c|c|}
\hline Sub-Scale & Group & $\mathbf{N}$ & $\overline{\mathbf{X}}$ & $\mathbf{S S}$ & sd & $\bar{t}$ & $\bar{p}$ \\
\hline Rejection and Ignorance & $\begin{array}{l}\text { Post-test } \\
\text { Retention }\end{array}$ & $\begin{array}{l}60 \\
60\end{array}$ & $\begin{array}{l}6,88 \\
6,87\end{array}$ & $\begin{array}{l}, 174 \\
, 171\end{array}$ & 59 & 1,125 & ,265 \\
\hline $\begin{array}{l}\text { Humiliation and Witnessing the } \\
\text { Child }\end{array}$ & $\begin{array}{l}\text { Post-test } \\
\text { Retention }\end{array}$ & $\begin{array}{l}60 \\
60\end{array}$ & $\begin{array}{l}6,84 \\
6,83\end{array}$ & $\begin{array}{l}, 188 \\
, 216\end{array}$ & 59 & ,905 & ,369 \\
\hline Isolation and Threatening & $\begin{array}{l}\text { Post-test } \\
\text { Retention }\end{array}$ & $\begin{array}{l}60 \\
60\end{array}$ & $\begin{array}{l}6,81 \\
6,81\end{array}$ & $\begin{array}{l}178 \\
, 188\end{array}$ & 59 &, 173 & ,864 \\
\hline Comparison and Discrimination & $\begin{array}{l}\text { Post-test } \\
\text { Retention }\end{array}$ & $\begin{array}{l}60 \\
60\end{array}$ & $\begin{array}{l}6,74 \\
6,73\end{array}$ & $\begin{array}{l}, 292 \\
, 278\end{array}$ & 59 & ,565 & ,574 \\
\hline KAENS Total & $\begin{array}{l}\text { Post-test } \\
\text { Retention }\end{array}$ & $\begin{array}{l}60 \\
60\end{array}$ & $\begin{array}{l}6,82 \\
6,80\end{array}$ & $\begin{array}{l}173 \\
, 160\end{array}$ & 59 & 1,145 & ,257 \\
\hline
\end{tabular}

As seen in Table 6, there is no statistically significant difference in the mean scores obtained by the training group on the KAENS' sub-scale RI $[\mathrm{t}(59)=1.125, \mathrm{p}>.05]$, the sub-scale HWC $[\mathrm{t}(59)=.905$, p $>.05]$, the sub-scale $\operatorname{IT}[\mathrm{t}(59)=.173, \mathrm{p}>.05]$, the sub-scale $\mathrm{CD}[\mathrm{t}(59)=.565, \mathrm{p}>.05]$ the total $\operatorname{KAENS}[\mathrm{t}(59)=1.145, \mathrm{p}>.05]$.

The results show that the effect of the program is retained. According to the results of the retention test performed four weeks after the post-test, the "Training Program to Promote Preservice Preschool Teachers' Knowledge and Awareness of Emotional Neglect and Abuse" administered to the training group has a permanent effect. The literature includes a limited volume of research on the retention of informative training in abuse. Leventhal (2001) investigated the effectiveness of preventive interventions and argued that parental programs 
including home visits were useful for families due to their effects lasting for many years. Çeçen-Eroğul and KafHasırcı (2013) noted that the arising change was retained according to the follow-up study conducted eight weeks after the experimental program. These research results support the result of the present study indicating the permanent effect of the training program. The use of everyday life examples in the program seems to be influential the permanence of participants' increased level of knowledge and awareness.

\subsection{The ANOVA Results of the Effectiveness and Retention of the Training Program to Promote} Preservice Preschool Teachers' Knowledge and Awareness of Emotional Neglect and Abuse

Tables 7 and 8 show the results of one-way ANOVA for repeated measures as a more powerful statistical method used to statistically support t-test results for the multiple comparisons of the mean pre-test, post-test and retention test scores of the participants in the training group.

Table-7. Distribution of the Pre-Test, Post-Test, Retention Scores of the Training Group

\begin{tabular}{l|l|l|l|l}
\hline Sub-Scale & Group & $\mathbf{N}$ & $\overline{\mathbf{X}}$ & SS \\
\hline Rejection And Ignorance & Pre-test & 60 & 6,42 &, 512 \\
\hline & Post-test & 60 & 6,88 &, 174 \\
\hline & Retention & 60 & 6,87 &, 171 \\
\hline Humiliation And & Pre-test & 60 & 6,33 &, 508 \\
\hline Witnessing The Child & Post-test & 60 & 6,84 &, 188 \\
\hline & Retention & 60 & 6,83 &, 216 \\
\hline Isolation And Threatening & Pre-test & 60 & 5,85 &, 508 \\
\hline & Post-test & 60 & 6,81 &, 178 \\
\hline & Retention & 60 & 6,81 &, 188 \\
\hline Comparison and & Pre-test & 60 & 6,03 &, 574 \\
\hline Discrimination & Post-test & 60 & 6,74 &, 292 \\
\hline & Retention & 60 & 6,73 &, 278 \\
\hline KAENS Total & Pre-test & 60 & 6,15 &, 344 \\
\hline & Post-test & 60 & 6,82 &, 173 \\
\hline & Retention & 60 & 6,80 &, 167 \\
\hline
\end{tabular}

Table-8. ANOVA Results of the Pre-Test, Post-Test, Retention Scores of the Training Group

\begin{tabular}{|c|c|c|c|c|c|c|c|}
\hline Sub-Scale & Source & Sum of Square & sd & Mean square & $\mathbf{F}$ & p & Mean dif.* \\
\hline & Conditions & 8,548 & 59 & , 145 & & & \\
\hline Rejection And & Subjects & 8,286 & 1,036 & 7,998 & 46,726 & , 000 & $2-1,3-1$ \\
\hline \multirow[t]{3}{*}{ Ignorance } & Error & 10,463 & 61,127 &, 171 & & & \\
\hline & Total & 27,297 & 121,163 & & & & \\
\hline & Conditions & 8,014 & 59 & , 136 & & & \\
\hline Humiliation and & Subjects & 10,171 & 1,071 & 9,496 & 49,434 & ,000 & $2-1,3-1$ \\
\hline Witnessing the & Error & 12,140 & 63,193 &, 192 & & & \\
\hline \multirow[t]{2}{*}{ Child } & Total & 30,325 & 123,264 & & & & \\
\hline & Conditions & 8,121 & 59 &, 138 & & & \\
\hline Isolation and & Subjects & 36,609 & 1,119 & 32,722 & 194,158 & , OOO & $2-1,3-1$ \\
\hline \multirow[t]{3}{*}{ Threatening } & Error & 11,125 & 66,008 &, 169 & & & \\
\hline & Total & 55,855 & 126,127 & & & & \\
\hline & Conditions & 11,901 & 59 & ,202 & & & \\
\hline Comparison and & Subjects & 19,657 & 1,235 & 15,922 & 67,441 & , OOO & $2-1,3-1$ \\
\hline \multirow[t]{3}{*}{ Discrimination } & Error & 17,197 & 72,839 & ,236 & & & \\
\hline & Total & 48,755 & 133,074 & & & & \\
\hline & Conditions & 4,744 & 59 & 0,080 & & & \\
\hline \multirow[t]{3}{*}{ Total } & Subjects & 17,583 & 1,080 & 16,283 & 187,040 & ,000 & $2-1,3-1$ \\
\hline & Error & 5,546 & 63,711 & 0,047 & & & \\
\hline & Total & 27,873 & 123,791 & & & & \\
\hline
\end{tabular}

1 Pre-test, 2 Post-test, 3 Retention

As seen Table 8, there is a significant difference in the mean pre-test, post-test and retention test scores of the training group on the KAENS' sub-scale RI $(\mathrm{F}=46.726$; $\mathrm{p}<0.05)$. According to the results of Bonferroni multiple compariPost-test to determine from which test scores this difference stems, there is a significant difference between the mean pre-test and post-test scores and between the mean pre-test and retention test scores of the training group. However, there is no statistically significant difference between the mean post-test and retention scores.

There is also a significant difference between the mean pre-test, post-test and retention test scores of the training group on the KAENS' sub-scale $\operatorname{HWC}(\mathrm{F}=49.434 ; \mathrm{p}<0.05)$. The results of Bonferroni multiple compariPost-test indicate a significant difference between the mean pre-test and post-test scores and between the mean pre-test and retention test scores of the training group. However, there is no statistically significant difference between the mean post-test and retention scores.

There is also a significant difference between the mean pre-test, post-test and retention test scores of the training group on the KAENS' sub-scale IT $(\mathrm{F}=194.158$; $\mathrm{p}<0.05)$. According to the results of Bonferroni multiple compariPost-test, there is a significant difference between the mean pre-test and post-test scores and between the mean pre-test and retention test scores of the training group. However, there is no statistically significant difference between the mean post-test and retention scores.

There is also a significant difference between the mean pre-test, post-test and retention test scores of the training group on the KAENS' sub-scale $\mathrm{CD}(\mathrm{F}=67.441 ; \mathrm{p}<0.05)$. The results of Bonferroni multiple compariPost- 
test indicate a significant difference between the mean pre-test and post-test scores and between the mean pre-test and retention test scores of the training group. However, there is no statistically significant difference between the mean post-test and retention scores.

There is also a significant difference between the mean pre-test, post-test and retention test scores of the training group on the total KAENS ( $\mathrm{F}=187.040 ; \mathrm{p}<0.05)$. According to the results of Bonferroni multiple compariPost-test, there is a significant difference between the mean pre-test and post-test scores and between the mean pre-test and retention test scores of the training group. However, there is no statistically significant difference between the mean post-test and retention scores.

As a result of the one-way ANOVA for repeated measures, a significant difference is expected in the mean pretest, post-test and retention test scores of the training group. It is an expected result that this difference occurs between the mean pre-test and post-test scores and between the mean pre-test and retention test scores since it indicates that the Training Program to Promote Preservice Preschool Teachers' Knowledge and Awareness of Emotional Neglect and Abuse is effective and its effect is permanent. Accordingly, the aforediscussed results of the total scale and sub-scales confirm that the Training Program to Promote Preservice Preschool Teachers' Knowledge and Awareness of Emotional Neglect and Abuse is effective and permanent.

\section{Conclusion}

This study conducted to analyze the effect of the Training Program to Promote Preservice Preschool Teachers' Knowledge and Awareness of Emotional Neglect and Abuse has found the following:

There is a significant difference in the mean pre-test scores of the training group and non-training group. There is also a significant difference in the mean pre-test and post-test scores of the training group.

There is no significant difference in the mean pre-test and post-test scores of the non-training group.

There is a significant difference in the mean post-test scores of the training group and non-training group.

There is no significant difference in the mean post-test and retention test scores of the training group.

According to the results of one-way ANOVA for the multiple comparisons of the pre-test, post-test and retention test scores, there is no significant difference in the scores.

There is a significant difference in the pre-test, post-test and retention test scores of the training group on the total scale. According to the results of Bonferroni multiple compariPost-test, there is a significant difference between the mean pre-test and post-test scores and between the mean pre-test and retention test scores of the training group. However, there is no statistically significant difference between the mean post-test and retention scores.

\subsection{Suggestions}

All in all, the study analyzing the effect of the Training Program to Promote Preservice Preschool Teachers' Knowledge and Awareness of Emotional Neglect and Abuse has found a post-training increase in the training group's level of knowledge and awareness compared to the non-training group. This results evidence the effectiveness of the training program administered to the training group. According to the results of the retention test conducted on the training group four weeks after the post-test, the training program seems to have a permanent effect.

The present study has revealed that preservice preschool teachers' knowledge and awareness of emotional neglect and abuse can be fostered through the training program. When preservice preschool teachers are aware of emotional neglect and abuse, it is a major step in preventing abuse at an early age. Accordingly, this study offers the following suggestions:

- The Training Program to Promote Preservice Preschool Teachers' Knowledge and Awareness of Emotional Neglect and Abuse can be provided to in-service teachers working in schools affiliated to the Ministry of National Education.

- The Training Program to Promote Preservice Preschool Teachers' Knowledge and Awareness of Emotional Neglect and Abuse can be introduced in faculties of education in universities. The training program can be generalized to preservice teachers of other branches besides preservice preschool teachers and administered within the scope of a course.

- This study uses a pre-test, post-test and retention test control group design and further research can employ a single group design.

- The Training Program to Promote Preservice Preschool Teachers' Knowledge and Awareness of Emotional Neglect and Abuse can be adapted for parents and further research can investigate the effect of the training program on parents.

\section{References}

Bolen, R.M., 2003. Child sexual abuse: Prevention or promotion? Social Work, 48(2): 174-185. View at Google Scholar

Büyüköztürk, Ş., 2002. Manual of data analysis for social sciences. Ankara: Pegem A.

Büyüköztürk, Ş., 2009. Manual of data analysis for social sciences. Ankara: Pegem A.

Campbell, H. and A. Wigglesworth, 2005. Child protection in schools: A survey of the training needs of school teachers. Public Health, $107(6): 413-419$.

Can-Yaşar, M., G. İnal-Kızıltepe and A. Kandır, 2014. Teacher candidates' awareness of physical abuse. Journal of Theoretical Education, 7(3): 286-303

Can, A., 2014. SPSS quantitative data analysis in the scientific research process. 2nd Edn., Ankara: Pegem A.

Çeçen-Eroğul, A.R. and Ö. Kaf-Hasırcı, 2013. Testing the efficacy of the sexual abuse prevention psycho-education program developed for elementary school primary level students. Educational Sciences in Theory and Practice, 13(2): 719-729.

Erol, D., 2007. Awareness of the teachers working in preschool institutions about the symptoms of physical abuse in children (Eskişehir Province Example). Master Thesis. Anadolu University Educational Sciences Institute, Eskişehir.

Hebert, M., F. Lavoie, C. Piche and M. Poitras, 2001. Proximate effects of a child sexual abuse prevention program in elementary school children. Child Abuse and Neglect, 25(4): 505-522. View at Google Scholar | View at Publisher

Kaptan, S., 1998. Scientific research and statistics techniques. Ankara: Uncle.

Karasar, N., 2006. Scientific research method. 16th Edn., Ankara: Nobel. 
Ko, S.F. and A.C. Merith, 2001. Do elementary school-based child abuse prevention programs work? A high school follow-up. Psychology in the Schools, 38(1): 57-66. View at Google Scholar $\mid$ View at Publisher

Leventhal, J.M., 2001. The prevention of child abuse and neglect: Successfull youth of the blocks. Child Abuse and Neglect, $25(4)$ : 43 1-439. View at Google Scholar | View at Publisher

MacMillan, H.L., H.B. Thomas, E. Jameison, C.A. Walsh, M.H. Boyle, H.S. Shannon and A. Gafni, 2005. The effectiveness of home visitation by public health in prevention of the reccurnence of child physical abuse and neglecet: A randomised controlled trial. Lancet, 365(9473): 1786-1793. View at Google Scholar

Okoza, J., O. Aluede and A. Ojugo, 2011. Sex and class of secondary school students in experiencing emotional abuse by teachers in Edo state, Nigeria, Pertanika. Journal of Social Science and Humanities, 19(2): $385-392$. View at Google Scholar

Pala, B., 2011. The level of knowledge and awareness of your future teachers about child abuse and neglect. Tipta Expertise Thesis, Osmangazi University, Faculty of Medicine, Eskişehir.

Peterson, L., G. Tremblay, B. Ewigman and L. Saldana, 2003. Multilevel selected primary prevention of child maltreatment. Journal of Consulting and Clinical Psychology, 71(3): 601-612. View at Google Scholar |View at Publisher

Şahin, F. and U. Beyazova, 2001. The right of the child to protection from violence. National Education Journal, 151(3): 90-94.

Sahin, F. and M.A. Taşar, 2012. Shaken baby syndrome and prevention programs. Journal of Turkish Pediatry Archives, 47: 152-158.

Sarı, I., 2010. Determination of the physical abuse potential of the parents in the police organization and the effectiveness of the family education program related to abuse. Doctoral Thesis, Gazi University Institute of Educational Sciences, Ankara.

Tugay, D., 2008. Awareness levels of teachers on child abuse and neglect. Master Thesis, Marmara University Health Sciences Institute, Istanbul.

Uçar, M., 2014. An examination of the effectiveness of the sexual abuse prevention curriculum prepared on the basis of the cognitive process approach. Master Thesis, Abant İzzet Baysal University Educational Sciences Institute, Bolu.

Walsh, K., R. Bridgstock, A. Farrell and R. Schweitzer, 2005. Critical factors in teachers detecting and reporting child abuse and neglect: Implications for practice. Queensland: Queensland University of Technology.

Yavuzer, H., 1992. Parents and children. Istanbul: Remzi. 